\title{
The ascent of man? Emil du Bois-Reymond's reflections on scientific progress
}

\author{
Gabriel Finkelstein \\ Triumphalist histories of science are nothing new but were, in fact, a staple of the 19th century. This article \\ considers one of the more famous works in the genre and argues that it was motivated by doubt more \\ than by faith.
}

Emil du Bois-Reymond was a 19th century physiologist best remembered for his mechanistic view of life and for his essays on science and culture. He was born into the Bildungsbürgertum, that elite and somewhat anxious social class central to discussions of modern German society. His parents were about as well established as was possible for Bürger in Biedermeier Berlin. His father (Figure 1), a poor Swiss Huguenot, had worked his way through the ranks of the foreign office until he became court counsellor for the affairs of Neuchâtel, a position that he held until his early retirement in 1848, when revolution gained the canton independence from the Prussian crown. His mother had an even better pedigree from one of the oldest and most prominent of Berlin's Huguenot families: her great-greatgrandfather had been the city's first established silk dyer ${ }^{1}$, her grandfather was director of Berlin's Academy of Fine Arts and the city's most famous engraver ${ }^{2}$, and her father was pastor of the French church, librarian to the King and director of the state artists' guild.

With such breeding, Emil du Bois-Reymond received an outstanding education, accompanying his father to Switzerland on official tours of inspection, learning to draw from his aunt ${ }^{3}$, polishing his French style at home and mixing with the wide circle of his family's friends and relations (Figures 2,3). To complete his studies, he attended the Französische Gymnasium and the University of Berlin, two of Germany's best schools, where he learned a broad range of academic subjects before switching to the faculty of medicine in his sixth semester. In 1841, his advisor asked him to look into Carlo Matteucci's treatise on animal electricity. This he did - in fact, du Bois-Reymond spent the rest of his scientific life looking into the topic. The first two volumes of his Investigations in Animal Electricity appeared in 1848 and 1849 , and ran to over 1400 pages; in 1884, he

\section{Gabriel Finkelstein}

Teaches History of Science and European History at the University of Colorado at Denver. He is currently completing a biography of the physiologist and essayist Emil du Bois-Reymond (18181896) and is planning a book on German scientific exploration. His research concerns the role of science in 19th-century German society.

gfinkels@ carbon.cudenver.edu published a third volume to this truncated masterpiece 4 . This research established electrophysiology as a scientific discipline. It also made du Bois-Reymond's career, earning him a seat in the Prussian Academy of Sciences, a professorship in physiology at the University of Berlin, oversight of the Berlin Physiological Society and Directorship of Berlin's first Institute of Physiology.

\section{The 'frog doctor'}

Du Bois-Reymond's scientific achievements can be divided between theory, experiment and technique. With regard to the first category, he expounded one of the principal statements of biological reductionism. Du BoisReymond conceived of living things as subject to the laws of chemistry and physics, a view expressed most clearly in the introduction to his 1848 treatise on animal electricity. At the time, revolution was sweeping through Berlin, and

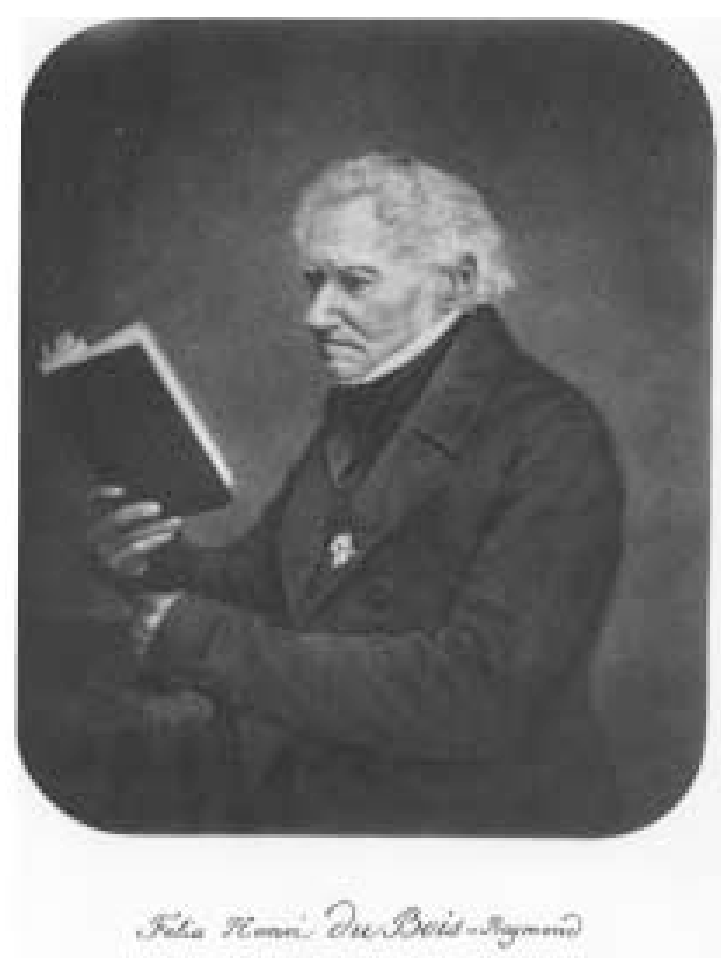

Figure 1 Emil du Bois-Reymond's father Felix. 


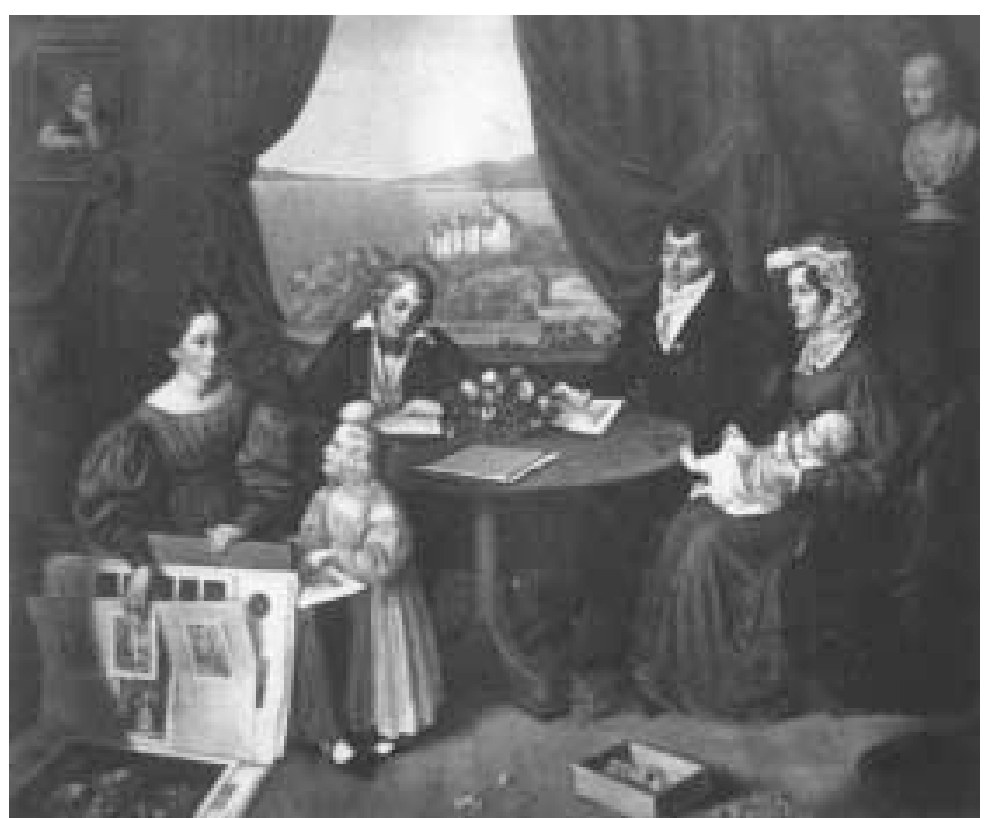

Figure 2 Emil du Bois-Reymond's family at home. Clockwise from bottom: his older sister Félicie, his aunt Louise, Emil himself, his father, his mother and his younger brother Paul. The landscape behind Emil looks like Neuchâtel, where the family stayed between 1830 and 1831 . The painting is a composite of portrait and memory: Paul was born after the du Bois-Reymonds returned from Switzerland.

\section{Survival of the fittest}

When he was around 40, du Bois-Reymond saw his scientific development stagnate. He had just become professor and the burdens of lectures, examinations and committees weighed on him. In his frustration, he began to write and, somewhat to his surprise, he found an interested public. Du Bois-Reymond's addresses were remarkable for their range and style. His favoured genre was biography, or perhaps one should say autobiography, because he portrayed all his subjects (Voltaire, Diderot, La Mettrie, Maupertuis, Chamisso, Erman, Müller, Helmholtz and even Goethe and Frederick the Great) in his own image. His histories shared the same bias. Whether he treated animal electricity, experimental physiology, European education or Western civilization, he always left his readers with the impression that the highest stage of development had been achieved in Prussian universities. This tendency to conflate self and other makes his writings hard to judge. They alternate between scholarship and art, and, at an even deeper level of ambiguity, between sensitivity and solipsism.

Characteristic in this regard was his essay 'Science and Cultural History', a speech that he delivered on 24 March 1877 at the Society for Scholarly Lectures in Cologne ${ }^{8}$. The date and location are significant: this was the height of the Kulturkampf and du Bois-Reymond intended to take the battle straight to the enemy. From our perspective, there is something faintly absurd in the thought of a 59-yearold Prussian professor going to Cologne to argue for the importance of science in civilization. We see a man speaking before an audience and, just outside, perhaps visible

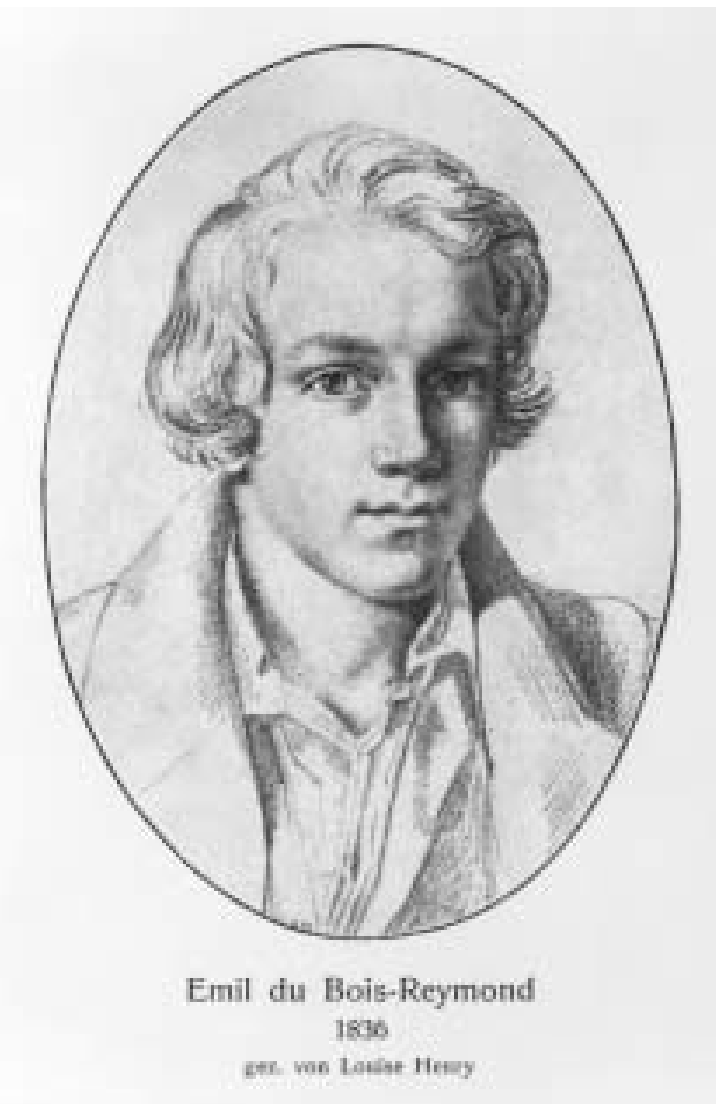

Figure 3 Emil du Bois-Reymond, age 18, drawn by his aunt Louise. 
through the window, we see an enormous Gothic cathedral, only recently completed after centuries of work, the symbol of Christian German unity become symbol of Catholic Reaction. On the one hand, the authority of education, reason and science; on the other, that of tradition, faith and the Church.

The first part of his speech did nothing to dispel this simple division of value. Du Bois-Reymond recounted the ages of man and, with them, his slow ascent out of barbarity and ignorance. The Stone Age, or 'childhood of the race', possessed no science at all, apart from the flint weapons that accompany every find of prehistoric artefacts. The 'Anthropomorphic Age', as he called the next stage of history, showed little progress. Simple inference enabled man to personify nature, offering a source of religion, if not its absolute cause. The 'somewhat shallow rationalism' of Buckle's and Lecky's determinist histories, which aligned myth with environment, were to be avoided lest we fool ourselves into thinking that we could derive monotheism from the harsh and unvaried aspect of the Semitic desert.

Du Bois-Reymond next criticized Greece and Rome. In no way did Classical science equal its achievements in the fields of art, literature, history, jurisprudence, rhetoric, metaphysics, war and administration. The ancients were certainly good engineers, but so were the Egyptians, Assyrians, Indians and Incas. The Chinese possessed better textiles and ceramics, and they also developed the compass, gunpowder and printing. Even the Aztecs kept a zoo. The relative values of art and science in the Classical world were manifest in its money: splendid portraits decorating coins the minters did not know how to make round.

The ancient world fell because it lacked vision. Du Bois-Reymond meant this literally: had Roman craftsmen studied nature with the attention that they devoted to sculpture, they might have developed the technology to stave off the barbarians. Like many contemporaries, du BoisReymond ascribed Prussia's recent victories to superior weapons, communications and railways, advantages, he argued, ultimately based on science. 'It was the University of Berlin that triumphed at Sadowa', a French historian observed $^{9}$. If true for Paris, why not also for Rome?

The Middle Ages confounded him. Du Bois-Reymond's synopsis of the period rehearsed a litany of intellectual evils: obsession with sin, stultifying ignorance, popular superstition and pointless scholasticism, all of which warned of the consequences of ignoring the natural world. One benefit nevertheless did accrue from Christianity: the idea of absolute truth encouraged rational inquiry.

$\mathrm{Du}$ Bois-Reymond's survey of cultural evolution culminated in what he called the 'Technical-Inductive Age', a true break with the past. Perhaps the most significant of the changes brought by science is our conception of history. As the one human endeavour that can be said to progress, "science is the absolute organ of culture, and the history of science the essential history of humanity' ${ }^{10}$. No other sphere of civilization can make this claim - not art, not politics, and certainly not morality. For what else has history taught us? Isn't the traditional discipline simply a pathetic chronicle, one which:

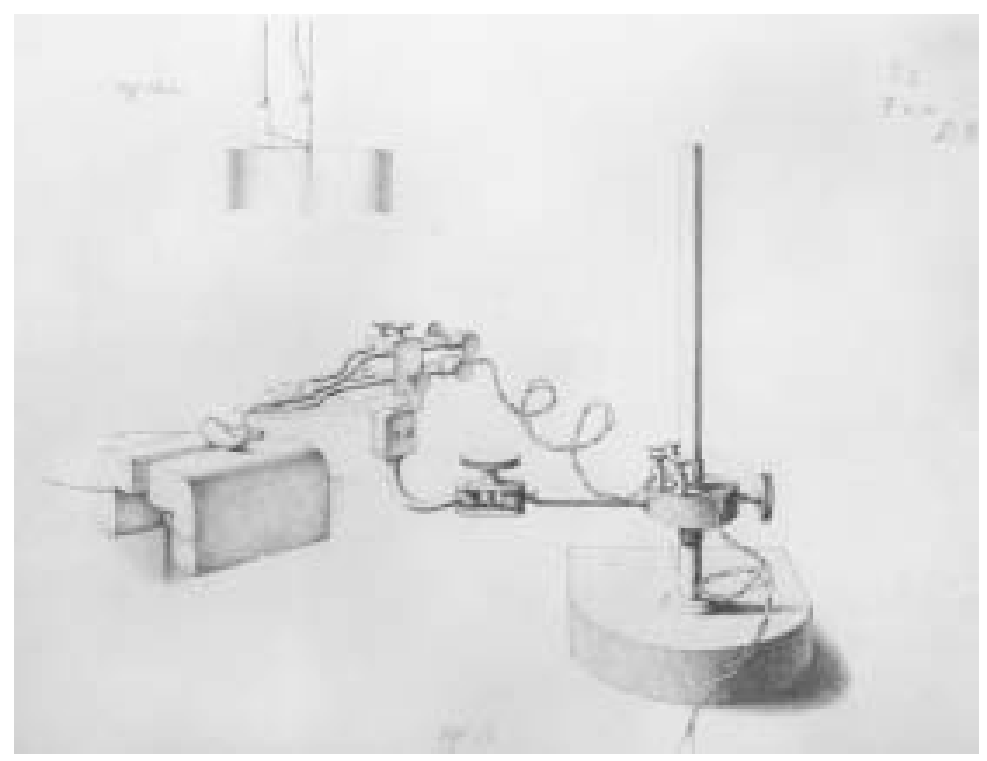

Figure 4 Du Bois-Reymond's laboratory apparatus for observing the negative variation. Top: metal electrodes for stimulating the nerve. Bottom: arrangement for detecting the negative variation in the muscular current. The frog thigh muscle rests across two thick paper conducting pads bent over the edges of the saline deriving vessels. (The rest of the circuit extending to the galvanometer is not shown.) Metal electrodes, held in place by an adjustable stand, stimulate the nerve. The twisted wires trail off to some source of electricity, most probably a magneto-electrometer.

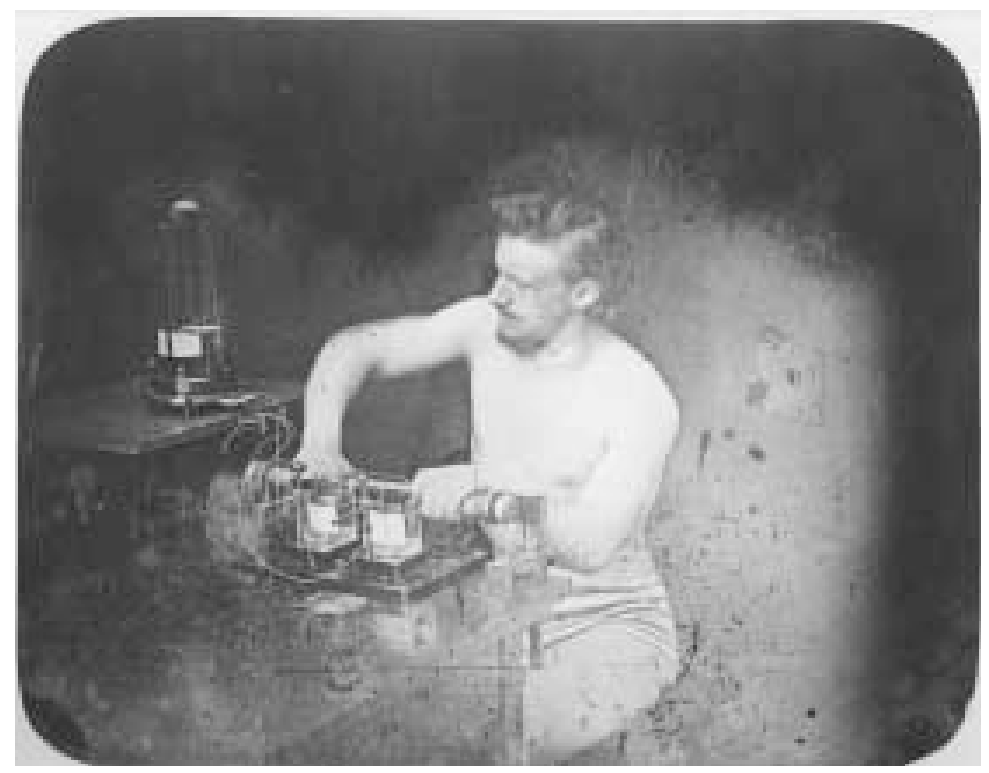

Figure 5 An early daguerreotype of Emil du Bois-Reymond demonstrating the existence of the 'voluntary tetanic current', or nervous signal, by tensing his right arm. His fingers dangle in saline deriving vessels. Wire leads run to the galvanometer on the table to his right. The galvanometer needle, which is suspended from the thread in the glass bell, swings at the moment of muscular effort. Du Bois-Reymond is unclothed to prevent static interference.

tells us of nothing other than the rise and fall of kings and empires, of treaties and inheritance claims, of wars and conquests, of battles and sieges, of rebellions and party struggles, of wasted cities and pogroms, of murders and executions, of palace plots and priestly intrigues; which shows us nothing in the war of all against all except a dismal muddle of ambition, avarice, and sensuality, of violence, betrayal, and revenge, of delusion, superstition, and hypocrisy? ${ }^{11}$

I submit that du Bois-Reymond's celebration of science expressed an essential pessimism. 


\section{Whistling in the dark?}

There are three reasons for the bleakness of his outlook. The first is personal and therefore of greatest interest to those historians who side with Carlyle and Froude, seeing history as the story of individual lives. I mentioned earlier that du Bois-Reymond's career in science had stalled. Perhaps I should add that his role in the Kulturkampf had made him an object of hate, that his wife's inheritance was evaporating in bad investments and that he was simply quick to mistrust, or at least had been since the age of ten, when his younger brother died and his parents never let him forget it.

The second reason is social and most convincing to those who want to anchor history to the structures of status and power. Du Bois-Reymond's class always claimed to speak in the interests of the entire nation and, for three or four decades in the middle of the 19th century, that claim had seemed plausible. By the 1870s, however, things had changed irrevocably. Improvements in literacy, transportation and wages had removed politics from the control of elites. Liberal ascendancy came to its end and, with it, the confidence that its values would prevail. 'Is continual progress manifest in the forces governing bourgeois history' ${ }^{2}$ ? Du Bois-Reymond's history of culture, like those of Hippolyte Taine or Henry Adams, resembled a funeral oration.

The last reason is intellectual. Du Bois-Reymond was one of the first converts to Darwin in Germany ${ }^{13}$. Darwin held that man descended from apes. If man acted like an animal, it was because he was an animal. Du Bois-Reymond professed his faith in science because it was his only faith left to profess.

\section{Notes and references}

1 Etienne Henry

2 Daniel Chodowiecki

3 Susette Henry

4 du Bois-Reymond, E. (1848-1884) Untersuchungen über thierische Elektricität (2 Vols), Reimer

5 du Bois-Reymond, E. (1848-1884) Untersuchungen über thierische Elektricität (Vol. 1), p. xv, Reimer

6 One of du Bois-Reymond's own students, Ludimar Hermann, later showed this to be an erroneous artefact of injury sustained by the animal preparation

7 Frank, R.G., Jr (1994) Instruments, nerve action, and the all-or-nothing principle. Osiris (2nd Ser.) 9, 208-235; Neher, E. and Sakmann, B. (1992) The patch clamp technique. Sci. Am. 266, 44-51

8 du Bois-Reymond, E. (1912) Kulturgeschichte und Naturwissenschaft. In Reden (2nd edn) (Vol. 1) (du BoisReymond, E.), pp. 567-629, Veit

9 Emile Boutmy (1835-1906), friend of Hippolyte Taine, quoted in Smith, R. (1997) The Norton History of the Human Sciences, p. 750, Norton. Compare this with Pasteur, L. (1871) Quelques réflexions sur la science en France. In Oeuvres de Pasteur, réunies par Pasteur ValleryRadot (Vol. 7), pp. 199-221, Masson

10 du Bois-Reymond, E. (1912) Reden (2nd edn) (Vol. 1), p. 596 , Veit

11 du Bois-Reymond, E. (1912) Reden (2nd edn) (Vol. 1), pp. 593-594, Veit

12 du Bois-Reymond, E. (1912) Reden (2nd edn) (Vol. 1), p. 594, Veit

13 du Bois-Reymond, E. (1912) Darwin und Kopernicus. In Reden (2nd edn) (Vol. 2), pp. 243-248, Veit 